\title{
SIFAT FISIK DAN KANDUNGAN GIZI BUAH PELUNTAN, SENARE, DAN ARA' DI KALIMANTAN BARAT
}

\author{
Niagara ${ }^{1}$, Entin Daningsih ${ }^{2}$, Titin $^{3}$ \\ ${ }^{1,2,3}$ Program Studi Pendidikan Biologi, FKIP, Universitas Tanjungpura, \\ Jalan Prof. Dr. H. Hadari Nawawi Pontianak 78124 \\ 'e-mail: niagara432@gmail.com
}

\begin{abstract}
Abstrak
Degradasi lingkungan berpengaruh terhadap hilangnya keanekaragaman buah hutan yang bersifat edibel di Kalimantan Barat. Penelitian bertujuan mengetahui sifat fisik dan kandungan gizi buah peluntan, senare, dan ara'. Bentuk penelitian terdiri dari deskriptif dan eksperimen. Teknik pengambilan sampel menggunakan simple random sampling. Penelitian deskriptif dilakukan pengamatan sifat fisik buah terhadap warna kulit muda dan matang, permukaan kulit, warna daging dan biji, ukuran buah dan biji, bentuk buah, jumlah biji, tekstur daging buah, rasa daging buah, serta aroma buah. Penelitian eksperimen dilakukan pengujian kandungan gizi diolah menggunakan aplikasi SAS versi 6.12 tahun 1996 dengan model RAL. Hasil sifat fisik buah memiliki perbedaan antarbuah peluntan, senare, dan ara'. Hasil analisis kandungan gizi buah menunjukkan bahwa terdapat perbedaan yang signifikan terhadap uji proksimat.
\end{abstract}

Kata Kunci: sifat fisik, kandungan gizi, peluntan, senare, ara’.

\begin{abstract}
Environmental degradation affects the loss of diversity of edible forest fruits in West Kalimantan. This study aimed to determine the physical properties and nutritional content of 'peluntan', 'senare', and' ara' fruits. The research consisted of descriptive and experimental forms. Sampling technique used simple random sampling. Descriptive research was carried out observe the physical properties of fruit to the skin color of young and mature, skin surface, color of meat and seeds, size of fruit and seed, fruit shape, number of seeds, fruit meat texture, fruit flesh taste, and fruit aroma. Experimental research was done by testing the nutrient content processed using SAS application version 6.12 of 1996 with RAL model. The results of the physical properties of the fruit have differences between fruit 'peluntan', 'senare', and' ara' fruits. The results of nutrient content showed there were significant differences in proximate test.
\end{abstract}

Keywords: physical properties, nutritional content, peluntan, senare, ara'.

\section{PENDAHULUAN}

Seiring bertambahnya waktu, keanekaragaman yang terdapat di hutan Kalimantan semakin berkurang. Banyak keanekaragaman hayati yang hilang akibat adanya alih fungsi hutan. Degradasi lingkungan berpengaruh terhadap keanekaragaman hayati yang ada di dalam hutan. Salah satu keanekaragaman hayati yang hilang adalah buah-buahan hutan yang bersifat edibel menjadi langka atau mulai jarang ditemui di Kalimantan Barat. Berdasarkan hasil penelitian LIPI- 
Bogor telah ditemukan 226 jenis (dari 35 suku) buah-buahan asli Kalimantan yang dapat dimakan, dari 226 jenis buah-buahan tersebut hanya 58 jenis yang telah dibudidayakan dan sisanya masih tumbuh liar di hutan-hutan (Uji, 2004).

Kurangnya pemanfaatan dan belum diketahui potensi dari buah-buahan hutan oleh masyarakat membuat buah-buahan yang ada di hutan menjadi langka. Masyarakat harus menyadari bahwa hutan Kalimantan kaya akan buah yang belum diketahui nilai potensinya. Buah kebanyakan mengandung vitamin $\mathrm{C}$ dan provitamin $\mathrm{A}$, terdapat juga kandungan vitamin $\mathrm{B}$, asam folat, vitamin $\mathrm{E}$, dan vitamin K (Ramayulis, 2016). Analisis kandungan gizi, bertujuan agar dapat diketahui kandungan gizi yang terkandung pada buah-buahan hutan tersebut. Masyarakat umum dapat mengetahui potensi dari buah hutan yang jarang dijumpai dan dapat membudidayakannya. Karena buah tersebut merupakan buah hutan yang sudah jarang ditemui, selain kandungan gizi yang terkandung didalamnya, maka perlu dilakukan pengamatan sifat fisik dari buah.

\section{METODE}

Penelitian terdiri dari penelitian deskriptif dengan pengamatan sifat fisik buah dan penelitian eksperimen dengan analisis kandungan gizi pada buah. Pengamatan sifat fisik dilaksanakan di hutan Desa Serimbu, Kecamatan Air Besar, Kabupaten Landak, Kalimantan Barat. Pengamatan dilakukan terhadap karakter sifat fisik buah yang meliputi warna kulit muda dan matang, permukaan kulit, warna daging dan biji, ukuran buah dan biji, bentuk buah, jumlah biji, tekstur daging buah, rasa daging buah, serta aroma buah. Tingkat kematangan buah menggunakan refractometer dan $\mathrm{pH}$ indikator universal.

Penelitian eksperimen menggunakan Rancangan Acak Lengkap (RAL), dengan 3 perlakuan, yaitu jenis buah peluntan, senare, dan ara'. Dari masingmasing buah dipilih 3 pohon yang berbeda. Untuk setiap pohon diambil minimal 3 buah agar dapat mencapai berat 168 gram. Analisis kandungan gizi buah dilaksanakan di Laboratorium Kimia Fakultas Pertanian Universitas Tanjungpura Pontianak dengan uji kadar karbohidrat total, kadar glukosa, fruktosa, sukrosa menggunakan benedict kuantitatif (Plummer, 1971), kadar protein menggunakan 
metode spektrofotometri, kadar lemak mengggunakan metode soxhlet, kadar vitamin $\mathrm{C}$ dengan cara metode titrasi yodium, kadar air dan kadar serat kasar menggunakan metode gravimetri, kadar abu dengan cara pengabuan secara langsung (Sudarmadji, dkk., 1997). Data hasil kandungan gizi diolah menggunakan aplikasi SAS versi 6.12 tahun 1996 dengan model RAL, dianalisis varian (ANOVA). Jika hasil menunjukkan pengaruh yang signifikan, maka dilanjutkan dengan uji Least Square Different (LSD).

\section{HASIL DAN PEMBAHASAN}

Sebelum dilakukan analisis kandungan gizi, terlebih dahulu dilakukan pengamatan terhadap sifat fisik buah peluntan, senare, dan ara'. Gambar fisik buah dapat dilihat pada Gambar 1, 2, dan 3. Hasil pengamatan sifat fisik buah dapat dilihat pada Tabel 1.
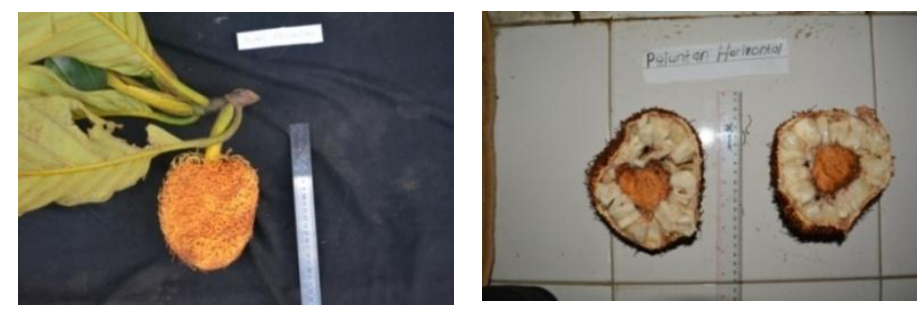

Gambar 1 Artocarpus sericicarpus (Buah Peluntan)
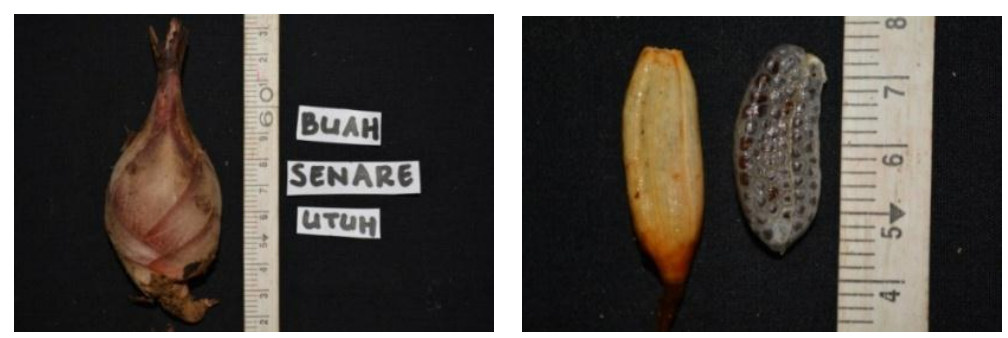

Gambar 2 Hornstedtia conica (Buah Senare)
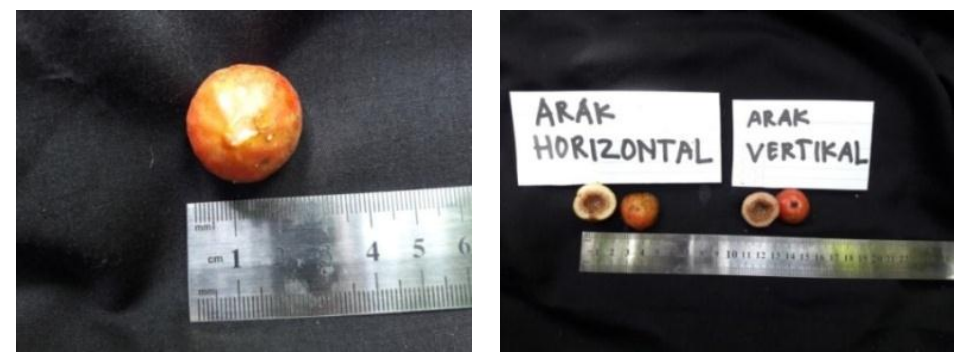

Gambar 3 Ficus racemosa (Buah Ara') 
Tabel 1 Sifat Fisik Buah Peluntan, Senare, dan Ara'

\begin{tabular}{|c|c|c|c|}
\hline Karakteristik & Peluntan & Senare & Ara' \\
\hline Warna kulit muda & Hijau & Putih, merah muda & Hijau \\
\hline Warna kulit matang & Jingga & $\begin{array}{l}\text { Merah muda, } \\
\text { kehitaman }\end{array}$ & Jingga kemerahan \\
\hline Permukaan kulit & $\begin{array}{c}\text { Kasar } \\
\text { berambut }\end{array}$ & $\begin{array}{l}\text { Luar: Kesat } \\
\text { Dalam: Licin } \\
\text { berlendir }\end{array}$ & Licin/halus \\
\hline Warna daging & Putih & Putih bening & Putih \\
\hline Warna biji & Putih & Hitam & Coklat \\
\hline Ukuran buah & $16-20 \mathrm{~cm}$ & $10-13 \mathrm{~cm}$ & $2-4 \mathrm{~cm}$ \\
\hline Bentuk buah & Bulat & Bulat Kerucut & Bulat \\
\hline Jumlah biji & Tak terhingga & Tak terhingga & Tak terhingga \\
\hline Ukuran biji & $1-2 \mathrm{~cm}$ & $0.1-0.2 \mathrm{~cm}$ & $0.1 \mathrm{~cm}$ \\
\hline Tekstur daging buah & Lembut padat & Lembut berbiji & Lembut padat \\
\hline Rasa daging buah & $\begin{array}{l}\text { Manis sedikit } \\
\text { asam }\end{array}$ & Asam manis & $\begin{array}{l}\text { Tawar agak } \\
\text { manis }\end{array}$ \\
\hline Aroma buah & $\begin{array}{c}\text { Wangi } \\
\text { beraroma } \\
\text { blewah }\end{array}$ & $\begin{array}{c}\text { Wangi beraroma } \\
\text { khas asam }\end{array}$ & $\begin{array}{c}\text { Wangi beraroma } \\
\text { madu }\end{array}$ \\
\hline
\end{tabular}

Berdasarkan hasil pengamatan, buah peluntan, senare, dan ara' memiliki sifat fisik yang berbeda. Perbedaan dari sifat fisik buah dapat memudahkan dalam mendeskripsikan dan menemukan buah peluntan, senare, ara' ketika di hutan. Buah peluntan memiliki ukuran buah yang lebih besar dibandingkan buah senare dan ara' yaitu 16-20 cm berbentuk bulat, pada permukaan kulitnya kasar berambut, dan memiliki aroma wangi seperti buah blewah. Buah peluntan memiliki famili dan genus yang sama dengan buah cempedak, nangka, sukun yaitu famili Moraceae dan genus Artocarpus. Pada buah senare berukuran 10-13 
cm berbentuk bulat kerucut tetapi ketika dibuka terdapat banyak buah berukuran 3-5 cm dengan permukaan licin berlendir, dan memiliki aroma khas asam. Pada buah ara' berukuran paling kecil dibandingkan buah peluntan dan senare yaitu 2-4 $\mathrm{cm}$ berbentuk bulat, pada permukaan kulitnya licin/halus, dan memiliki aroma wangi madu.

Analisis kadar gula dan kadar asam bertujuan untuk mengetahui tingkat kematangan buah saat dipetik dan ketika akan diuji.

Tabel 2 Kadar Gula dan Kadar Asam Buah Peluntan, Senare, dan Ara'

\begin{tabular}{lccc}
\hline & Peluntan & Senare & Ara' \\
\hline Saat dipetik & & & \\
Total kadar gula ('brix) & 25,67 & 23,0 & 5,67 \\
Total kadar asam & 5,3 & 3,3 & 4,67 \\
\hline Saat akan diuji & & & \\
Total kadar gula ('brix) & 21,67 & 22,0 & 5,67 \\
Total kadar asam & 5,0 & 3,0 & 4,67 \\
\hline
\end{tabular}

Total kadar gula pada setiap buah terdapat perbedaan saat dipetik dan akan diuji dengan mengalami penurunan dan kenaikan (Tabel 2) yang dapat diakibatkan oleh beberapa faktor. Buah digolongkan menjadi dua kelompok, yaitu klimakterik dan non-klimakterik. Klimakterik adalah kematangannya tidak perlu menunggu matang dipohon, namun demikian untuk menjaga kualitasnya, maka buah harus dipetik pada tingkat kematangan yang cukup. Non-klimakterik adalah tidak dapat matang setelah dipetik tetapi kualitasnya tetap saat dipetik dan disimpan beberapa lama (Antarlina, 2009).

Buah peluntan dapat digolongan buah klimakterik karena buah peluntan dapat matang walaupun sudah dipetik. Buah senare digolongan buah nonklimakterik karena buah senare tidak dapat matang lagi saat setelah dipetik (diperam) tetapi kualitas buah akan sama dengan saat dipetik atau dapat disimpan dalam jangka waktu yang lama jika pemetikannya tepat pada waktunya. Buah ara' digolongan buah non-klimakterik karena kualitas buah tetap sama setelah dipetik 
dan saat akan diuji. Menurut Nurjanah (2002) produksi etilen pada buah nonklimakterik cenderung konstan pada kondisi yang normal tanpa adanya perubahan lingkungan.

Total kadar asam sama halnya dengan total kadar gula pada setiap buah yang terdapat perbedaan saat dipetik dan akan diuji dengan mengalami penurunan dan kenaikan (Tabel 2). Total asam berhubungan dengan total kadar gula, jika kadar gula meningkat maka kadar asam menurun dan begitu pula sebaliknya. Hal tersebut sesuai dengan Antarlina (2009), yang menyatakan pada buah matang memiliki kadar gula yang lebih tinggi dibandingkan dengan buah muda (mentah). Sedangkan total asam buah muda lebih tinggi dibandingkan dengan buah yang sudah matang. Pantastico (Purwantiningsih, dkk., 2012) menyatakan makin matangnya buah, dapat diamati adanya kenaikan keasaman dalam daging buah. Semakin masaknya buah, kenaikan keasaman disebabkan oleh biosintesis asam oksalat yang berlebihan pada waktu buah masih hijau.

Tabel 3 Hasil Kandungan Gizi Buah Peluntan, Senare, dan Ara'

\begin{tabular}{lrrr}
\hline Parameter yang Diukur & Peluntan & Senare & Ara' \\
\hline Karbohidrat (gr/100gr) & $11,41 \mathrm{~b}$ & $47,05 \mathrm{a}$ & $6,16 \mathrm{c}$ \\
Glukosa (gr/100gr) & $9,04 \mathrm{~b}$ & $18,73 \mathrm{a}$ & $3,55 \mathrm{c}$ \\
Fruktosa (gr/100gr) & $9,59 \mathrm{~b}$ & $19,85 \mathrm{a}$ & $3,76 \mathrm{c}$ \\
Sukrosa (gr/100gr) & $8,87 \mathrm{~b}$ & $18,35 \mathrm{a}$ & $3,48 \mathrm{c}$ \\
Protein (gr/100gr) & $4,71 \mathrm{a}$ & $2,45 \mathrm{~b}$ & $0,77 \mathrm{c}$ \\
Lemak (gr/100gr) & $8,54 \mathrm{a}$ & $1,42 \mathrm{~b}$ & $0,82 \mathrm{c}$ \\
Air (gr/100gr) & $73,78 \mathrm{~b}$ & $47,65 \mathrm{c}$ & $91,32 \mathrm{a}$ \\
Abu (gr/100gr) & $1,57 \mathrm{a}$ & $1,43 \mathrm{a}$ & $0,93 \mathrm{~b}$ \\
Serat Kasar (gr/100gr) & $0,73 \mathrm{c}$ & $22,84 \mathrm{a}$ & $2,75 \mathrm{~b}$ \\
Vitamin C (mg/100gr) & $157,42 \mathrm{a}$ & $43,02 \mathrm{~b}$ & $37,17 \mathrm{c}$ \\
\hline
\end{tabular}

Keterangan: Huruf di belakang nilai mean antarbaris yang tidak sama menunjukkan adanya perbedaan yang signifikan antara setiap jenis buah ketika diuji LSD $\alpha=0,05$. 


\section{Uji Karbohidrat Total}

Uji karbohidrat total merupakan uji yang dilakukan untuk melihat kandungan karbohidrat secara keseluruhan dalam suatu sampel. Menurut Irianto (2007) karbohidrat merupakan senyawa sumber energi utama bagi tubuh. Buah yang memiliki kandungan karbohidrat tertinggi adalah buah senare dengan jumlah 47,05 gr memiliki perbedaan yang signifikan sekali terhadap buah peluntan dengan kadar karbohidrat 11,41 gr, dan buah ara' dengan kadar karbohidrat terendah yaitu 6,16 gr.

\section{Uji Kadar Glukosa, Fruktosa, dan Sukrosa}

Monosakarida (gula sederhana) adalah karbohidrat paling sederhana yang merupakan molekul terkecil karbohidrat. Dalam tubuh monosakarida langsung diserap oleh dinding-dinding usus halus dan masuk ke dalam peredaran darah. Glukosa dan fruktosa termasuk dalam kelompok monosakarida, sedangkan sukrosa termasuk ke dalam disakarida dimana disakarida merupakan gabungan dari dua macam monosakarida (Irianto, 2007).

Buah yang memiliki kandungan glukosa tertinggi adalah buah senare dengan jumlah 18,73 gr yang memiliki perbedaan signifikan sekali terhadap buah peluntan dan ara'. Buah peluntan memiliki kadar glukosa 9,04 gr memiliki perbedaan yang signifikan sekali terhadap buah ara' dengan kadar glukosa terendah yaitu 3,55 gr. Sedangkan pada kandungan fruktosa tertinggi adalah buah senare dengan kadar 19,85 gr memiliki perbedaan yang signifikan sekali terhadap buah peluntan dan ara'. Buah peluntan memiliki kadar fruktosa sejumlah 9,59 gr, memiliki perbedaan yang signifikan sekali terhadap buah ara' dengan kadar fruktosa terendah yaitu 3,76 gr. Buah yang memiliki kandungan sukrosa tertinggi adalah buah senare dengan jumlah 18,35 gr memiliki perbedaan yang signifikan sekali terhadap buah peluntan dan ara'. Buah peluntan memiliki kadar sukrosa sejumlah 8,87 gr, memiliki perbedaan yang signifikan sekali terhadap buah ara' dengan kadar sukrosa terendah yaitu 3,48 gr.

Kadar glukosa, fruktosa, dan sukrosa yang paling tinggi ialah buah senare tetapi memiliki rasa asam yang menandakan bahwa kaya akan vitamin $\mathrm{C}$. 
Berdasarkan morfologi buah senare terasa keras saat baru dipetik dan terlihat seperti buah yang masih muda tetapi sudah bisa dimakan. Menurut Rismunandar (Purwantiningsih, dkk., 2012) buah yang masih muda akan terasa keras yang diakibatkan oleh tekanan turgor yang tinggi dalam sel-sel yang masih muda, akibatnya enzim dalam mengubah gula-gula sederhana yang mudah larut dalam air, antara lain D-glukosa, sukrosa, fruktosa dan D-galaktosa menjadi vitamin C masih relatif sedikit. Buah yang baru dipetik dan umurnya terlalu muda, maka kandungan karbohidrat yang berupa gula-gula sederhana meningkat, sedangkan enzim-enzim yang terdapat dalam buah seperti katalase, amilase belum aktif bekerja dalam mengubah gula sederhana tersebut menjadi vitamin $\mathrm{C}$ (Purwantiningsih, dkk., 2012).

\section{Uji Serat Kasar}

Serat merupakan komponen dinding sel tanaman yang tak dapat dicerna oleh sistem pencernaan manusia. Serat bermanfaat untuk merangsang alat cerna agar mendapat cukup getah cerna, membentuk volume sehingga menimbulkan rasa kenyang dan membantu pembentukan feses (Irianto, 2007). Buah senare memiliki kadar serat kasar sebesar 22,84 gr, memiliki perbedaan yang signifikan sekali terhadap buah peluntan dan ara'. Buah ara' memiliki kadar serat kasar sejumlah 2,75 gr, sedangkan kadar serat kasar buah peluntan sebesar 0,73 gr.

Tingginya serat kasar pada buah senare seiring dengan tingginya kadar glukosa dan fruktosa yang termasuk golongan monosakarida, serat merupakan salah satu golongan dari polisakarida. Polisakarida (karbohidrat kompleks) merupakan gabungan beberapa molekul monosakarida, disebut polisakarida jika tersusun atas lebih dari 6 molekul monosakarida (Irianto, 2007).

\section{Uji Lemak}

Buah yang memiliki kandungan lemak tertinggi adalah buah peluntan dengan jumlah 8,54 gr, memiliki perbedaan yang signifikan sekali terhadap buah senare dengan kadar lemak 1,42 gr dan buah ara' dengan kadar lemak terendah yaitu 0,82 gr. Menurut Prabandari (2005) kandungan lemak yang rendah pada 
buah dan sayur mempunyai peranan penting dalam mempertahankan tekstur, rasa, aroma berupa trigliserida, sterol, dan kolesterol.

\section{Uji Protein}

Protein bagi tubuh sebagai sumber energi, membantu dan mempertahankan jaringan tubuh serta keseimbangan cairan, pembentuk hormon, mempertahankan fungsi imunitas tubuh (Purnakarya, 2009). Buah yang memiliki kandungan protein tertinggi adalah buah peluntan dengan jumlah 4,71 gr memiliki perbedaan yang signifikan sekali terhadap buah senare dengan kadar protein 2,45 gr dan buah ara' dengan kadar protein terendah yaitu $0,77 \mathrm{gr}$.

\section{Uji Air}

Air merupakan komponen terbesar dalam struktur tubuh manusia. Kurang lebih $60-70 \%$ berat badan orang dewasa berupa air sehingga air sangat diperlukan oleh tubuh. Air sebagai media transportasi zat-zat gizi, membuang sisa-sisa metabolisme, mengatur temperatur tubuh terutama disela aktivitas fisik, mempertahankan keseimbangan volume darah (Irianto, 2007).

Buah ara' memiliki kandungan air sebesar 91,32 gr, memiliki perbedaan yang signifikan sekali terhadap buah peluntan dan senare. Buah peluntan memiliki kadar air sejumlah 73,78 gr, memiliki perbedaan yang signifikan sekali terhadap buah senare dengan kadar air terendah yaitu 47,65 gr. Nofrianti dan Asni (2015) menyatakan bahwa semakin matang buah, maka kadar airnya akan semakin meningkat. Buah ara' memiliki kadar air tertinggi diantara dua buah lainnya.

\section{Uji Abu}

Kadar abu menggambarkan banyaknya mineral yang tidak terbakar menjadi zat yang mudah menguap (Nurwanto, 2003). Kadar abu merupakan parameter nilai gizi bahan makanan. Abu adalah zat anorganik yang dihasilkan dari sisa pembakaran suatu bahan organik. Sebagian besar bahan makanan, yaitu sekitar 96\% terdiri dari bahan organik dan air (Swastawati, dkk., 2013). Menurut Amelia, 
dkk. (2005) uji kadar abu sebagai indikator, semakin tinggi kadar abu dalam suatu bahan pangan, maka semakin buruk kualitas pangan tersebut.

Buah peluntan memiliki kadar abu lebih besar dibandingkan 2 buah lainnya yaitu sebesar 1,57 gr dan tidak berbeda nyata terhadap buah senare yang memiliki kadar abu sejumlah 1,43 gr, tetapi berbeda nyata terhadap buah ara' dengan kadar abu terendah yaitu 0,93 gr. Paling kecilnya kadar abu pada buah ara' ada hubungannya dengan tingginya kadar air pada buah ara'. Menurut Hiariey dan Lekahena (2015) besarnya kadar abu karena adanya perbedaan kadar air selama penyimpanan. Dengan berkurangnya kadar air dapat menyebabkan komponen protein, lemak, dan abu meningkat karena komponen tersebut masih terikat dalam air.

\section{Uji Vitamin C}

Beberapa vitamin dapat berperan mengatur fungsi tubuh, misalnya memacu dan memelihara pertumbuhan, reproduksi, kesehatan dan kekurangan tubuh, stabilitas sistem saraf, selera makan, pencernaan, penggunaan zat-zat makanan lainnya (Irianto, 2007). Buah peluntan memiliki kandungan vitamin C sebesar 157,42 mg dan berbeda nyata terhadap buah senare yang memiliki kadar vitamin C sejumlah 43,02 mg tetapi tidak berbeda nyata terhadap buah ara' dengan kadar vitamin C terendah yaitu $37.17 \mathrm{mg}$. Secara morfologi, buah peluntan memiliki rasa manis dan buah senare memiliki rasa asam. Tetapi hasil kadar vitamin $\mathrm{C}$ buah peluntan lebih tinggi dibandingkan dengan buah senare. Hal tersebut dapat disebabkan oleh beberapa faktor, misalnya faktor lama penyimpanan buah. Menurut Farikha, dkk. (2013) terjadinya penurunan kadar vitamin C juga disebabkan oleh suhu dan lama penyimpanan yang sinar atau cahaya matahari langsung dengan mudah menembus bahan dan mengoksidasi vitamin $\mathrm{C}$ yang ada pada sari buah. Hal ini dikarenakan vitamin $\mathrm{C}$ bersifat tidak stabil, mudah teroksidasi jika terkena udara (oksigen) dan proses ini dapat dipercepat oleh panas. Namun demikian, temperatur dan cahaya pada saat penyimpanan tidak diukur. 
Menurut Poedjiadi (2006) rasa asam pada buah tidak selalu sejalan dengan kadar vitamin C. Vitamin C dapat hilang karena pemanasan yang menyebabkan rusak, pencucian sebelum dipotong-potong, membuka tempat berisi vitamin $\mathrm{C}$ sebab udara akan terjadi oksidasi yang tidak reversible. Tingginya kadar air pada buah ara' mempengaruhi rendahnya vitamin $\mathrm{C}$ pada buah tersebut. Menurut Khoirunnisa dan Majid (2010) besarnya kadar air dalam masing-masing buah tersebut juga dapat mempengaruhi besarnya kadar vitamin $\mathrm{C}$ di dalam buah tersebut. Seperti telah diketahui bahwa vitamin C merupakan vitamin yang larut dalam air.

Berdasarkan hasil analisis, diketahui bahwa buah peluntan, senare, dan ara' memiliki nilai kandungan gizi buah berupa karbohidrat total, glukosa, fruktosa, sukrosa, protein, lemak, air, abu, serat kasar, dan vitamin $\mathrm{C}$ yang berbeda-beda. Buah peluntan memiliki kandungan protein, lemak, abu, dan vitamin $\mathrm{C}$ yang tinggi, buah senare memiliki kandungan karbohidrat total, glukosa, fruktosa, sukrosa, dan serat kasar yang tinggi dan buah ara' memiliki kandungan air yang tinggi. Menurut Susi (2014) buah tropis disebut juga sebagai buah eksotik yang merupakan sumber penting dari vitamin, serat, dan komponen gizi lainnya seperti antioksidan.

Selain kandungan gizi yang bertujuan untuk kesehatan, rasa dalam buah dapat meningkatkan kebutuhan buah. Buah peluntan, senare, dan ara' memiliki rasa manis, asam, dan dapat langsung dikonsumsi (Tabel 1). Menurut Susi (2014) buah eksotik memiliki rasa asam, manis, dan dapat dikonsumsi sebagai buah meja. Buah yang dimakan secara langsung biasanya buah yang memiliki rasa manis, asam, dan memiliki tekstur yang tidak terlalu keras.

Pemanfaatan tumbuhan buah edible oleh masyarakat dianggap masih kurang karena pemanfaatan buah edible dipengaruhi kualitas buah dan cita rasa buah. Kualitas buah yang baik dan rasanya yang enak akan dimanfaatkan relatif lebih banyak (Kurniawati, dkk., 2015). Pemanfaatan buah di Kalimantan Barat perlu ditingkatkan, mengingat bahwa buah hutan yang tumbuh secara liar memiliki kandungan gizi yang cukup untuk memenuhi kebutuhan sebagai sumber pangan dan bernilai ekonomi serta berpotensi untuk dikembangkan/dibudidayakan. 


\section{SIMPULAN}

Buah peluntan memiliki ukuran besar dan rasa buah manis sedikit asam, tekstur daging lembut padat. Buah senare memiliki rasa buah kombinasi antara asam dan manis, daging buah berbiji. Buah ara' memiliki rasa buah tawar agak manis, tekstur daging lembut, padat, berair aroma wangi khas seperti madu.

Buah peluntan memiliki kandungan protein, lemak, abu, dan vitamin $\mathrm{C}$ lebih tinggi dibandingkan dengan buah senare dan ara'. Buah senare memiliki kandungan karbohidrat total, glukosa, fruktosa, sukrosa, dan serat kasar lebih tinggi dibandingkan dengan buah peluntan dan ara'. Buah ara' memiliki kandungan air tertinggi dari buah peluntan dan senare.

Berdasarkan sifat fisik dan kandungan gizi buah peluntan, senare, dan ara' berpotensi untuk dibudidayakan dan dilestarikan. Konservasi perlu dilakukan mengingat hutan telah banyak dialih fungsikan sebagai perkebunan kelapa sawit dan karet.

\section{UCAPAN TERIMA KASIH}

Penulis mengucapkan terima kasih kepada tim payung penelitian buah langka dengan dana mandiri, FKIP Universitas Tanjungpura yang telah memberikan dana DIPA, dan Kepala Laboratorium Kimia Pangan Fakultas Pertanian Universitas Tanjungpura yang telah memfasilitasi sarana dan prasarana analisis kandungan gizi buah.

\section{DAFTAR PUSTAKA}

Amelia, M. R., Nina, D., Trisno, A., Julyanty, S. W., Rafika, N. F., \& Yuni, H. A. 2005. Penetapan Kadar Abu (AOAC). Jurnal Departemen Gizi Masyarakat. (Online, tersedia di http://www.academia.edu/, diakses Tanggal 15 Juli 2017).

Antarlina, S. S. 2009. Identifikasi Sifat Fisik dan Kimia Buah-buahan Lokal Kalimantan. Buletin Plasma Nutfah, 15(2): 80-90.

Farikha, I. N., Anam, C., \& Widowati, E. 2013. Pengaruh dan Konsentrasi Bahan Penstabil Alami Terhadap Karakteristik Fisikokimia Sari Buah Naga Merah 
(Hylocereus polyrhizus) Selama Penyimpanan. Jurnal Teknosains Pangan, 2(1): 30-38.

Hiariey, S. \& Lekahena, V. 2015. Pengaruh Pemberian Ekstrak Biji Atung Sebagai Pengawet Alami Terhadap Perubahan Nilai Mutu Ikan Tongkol Asap. Jurnal Pengolahan Hasil Perikanan Indonesia, 18(3): 329-340.

Irianto, D. P. 2007. Panduan Gizi Lengkap Keluarga dan Olahragawan. Yogyakarta: Andi Offset.

Khoirunnisa, F. \& Majid, A. 2010. Penentuan Kadar Vitamin C dan Kadar Serat Kasar yang Terkandung dalam Buah-buahan: Belimbing (Averhoa carambola), Mangga (Mangifera indica), Nanas (Ananas comosus), dan Pepaya (Carica papaya). Samarinda: Universitas Mulawarman.

Kurniawati, T. E., Turnip, M., \& Lovadi, I. 2015. Kajian Pemanfaatan Buah Edibel Suku Dayak Banyadu Di Hutan Tembawang Desa Setia Jaya Kecamatan Teriak Kabupaten Bengkayang. Jurnal Protobiont, 4(1): 10-16.

Nofrianti, D. \& Asni, N. 2015. Pengaruh Jenis Kemasan dan Tingkat Kematangan terhadap Kualitas Buah Jeruk Selama Penyimpanan. Jurnal Penelitian Pascapanen Pertanian, 12(2): 87-92.

Nurjanah, S. 2002. Kajian Laju Respirasi dan Produksi Etilen sebagai Dasar Penentuan Waktu Simpan Sayuran dan Buah-buahan. Jurnal Bionatura, 4(3): 148-156.

Nurwanto, M. S. 2003. Dasar Teknologi Hasil Peternakan. Semarang: Fakultas Peternakan Universitas Diponegoro.

Plummer, D. T. 1971. An Introduction to Practical Biochemistry. London, New York: McGraw-Hill.

Sudarmadji, S., Haryono, B., \& Suhardi. 1997. Prosedur Analisa untuk Bahan Makanan dan Pertanian. Yogyakarta: Liberty.

Poedjiadi, A. 2006. Biokimia. Jakarta: UI Press.

Purnakarya, I. 2009. Peran Zat Gizi Makro terhadap Kejadian Demensia pada Lansia. Studi Literatur. Jurnal Kesehatan Masyarakat, Volume 3.

Ramayulis, R. 2016. Super Jus. Jakarta: Penebar Swadaya Grup.

Susi. 2014. Potensi Pemanfaatan Nilai Gizi Buah Eksotik Khas Kalimantan Selatan. Ziraa'ah, 39 (3): 144-150. 
Swastawati, F., Surti, T., Agustini, T. W., \& Riyadi, P. H. 2013. Karakteristik Kualitas Ikan Asap yang Diproses Menggunakan Metode dan Jenis Ikan Berbeda. Jurnal Aplikasi Teknologi Pangan, Volume 2(3).

Uji, T. 2004. Keanekaragaman Jenis, Plasma Nutfah, dan Potensi Buah-Buahan Asli Kalimantan. Jurnal Ilmiah Biosmart, 6(2): 117-125. 